\title{
Challenges Related to the Processing of Fines in the Recovery of Platinum Group Minerals (PGMs)
}

\author{
Kirsten C. Corin ${ }^{1, *(\mathbb{D}, \text {, Belinda J. McFadzean }}{ }^{1}$, Natalie J. Shackleton ${ }^{2}{ }^{\mathbb{D}}$ and Cyril T. O'Connor ${ }^{1}$ \\ 1 Centre for Minerals Research, Chemical Engineering Department, University of Cape Town, P Bag X3, \\ Rondebosch, Cape Town 7700, South Africa; belinda.mcfadzean@uct.ac.za (B.J.M.); \\ cyril.oconnor@uct.ac.za (C.T.O.) \\ 2 Minerals Expertise Tech Pty Ltd., Germiston 2007, South Africa; natalieshackleton0@gmail.com \\ * Correspondence: Kirsten.Corin@uct.ac.za
}

Citation: Corin, K.C.; McFadzean, B.J.; Shackleton, N.J.; O'Connor, C.T. Challenges Related to the Processing of Fines in the Recovery of Platinum Group Minerals (PGMs). Minerals 2021, 11, 533. https://doi.org/ $10.3390 / \min 11050533$

Academic Editors: Lev Filippov and Daniel Fornasiero

Received: 23 April 2021

Accepted: 17 May 2021

Published: 18 May 2021

Publisher's Note: MDPI stays neutral with regard to jurisdictional claims in published maps and institutional affiliations.

Copyright: (c) 2021 by the authors. Licensee MDPI, Basel, Switzerland. This article is an open access article distributed under the terms and conditions of the Creative Commons Attribution (CC BY) license (https:// creativecommons.org/licenses/by/ $4.0 /)$.

\begin{abstract}
In order to increase the recovery of PGMs by flotation, it is necessary to optimise the liberation of the key minerals in which the platinum group elements (PGEs) are contained which include sulphides, arsenides, tellurides, and ferroalloys among others, while at the same time ensuring the optimal depression of gangue minerals. In order to achieve this, comminution circuits usually consist of two or three stages of milling, in which the first stage is autogeneous, followed by ball milling. Further liberation is achieved in subsequent stages using ultra-fine grinding. Each comminution stage is followed by flotation in the so-called MF2 or MF3 circuits. While this staged process increases overall recoveries, overgrinding may occur, hence creating problems associated with fine particle flotation. This paper presents an overview of the mineralogy of most of the more significant PGM ores processed in South Africa and the various technologies used in comminution circuits. The paper then summarises the methodology used in flotation circuits to optimise recovery of fine particles in terms of the collectors, depressants, and frothers used. The effect of entrainment, slimes coating, changes in rheology caused by the presence of a significant amount of fines and of chromite recovery is addressed.
\end{abstract}

Keywords: fines; PGMs; mineralogy; comminution; flotation; rheology

\section{Introduction}

The issues related to fine particle flotation have been extensively studied (e.g., [1,2]). It is generally accepted that many of these problems are owing to the low mass and high surface area of fine particles and a number of contributory factors that are usually interrelated [3]. All of these factors, which will be discussed below, have the potential to affect the flotation recovery and grade of the valuable product.

Gangue slimes can also create problems by coating fresh mineral surfaces, and this may be detrimental, in particular, for fines flotation [4]. Surface coatings of value bearing minerals by hydrophilic species reduces flotation recovery in all size fractions, but particularly for fine particles. Surface coatings affect fine particles more than coarse articles most likely due to the relative surface areas-fine particles are rendered hydrophilic by a lesser degree of surface coating.

It has however been shown that it is possible that the problems associated with fine flotation may be mitigated by improved circuit design (e.g., [5,6]). In the processing of PGMs, these include the widespread use of flow sheets which take into account multiple liberation/beneficiations and are referred to as MF (mill-float) 2 or MF3 flow sheets. Figure 1 shows a typical MF2 flowsheet. The advantages of such circuits are that they reduce the propensity of over-grinding. 


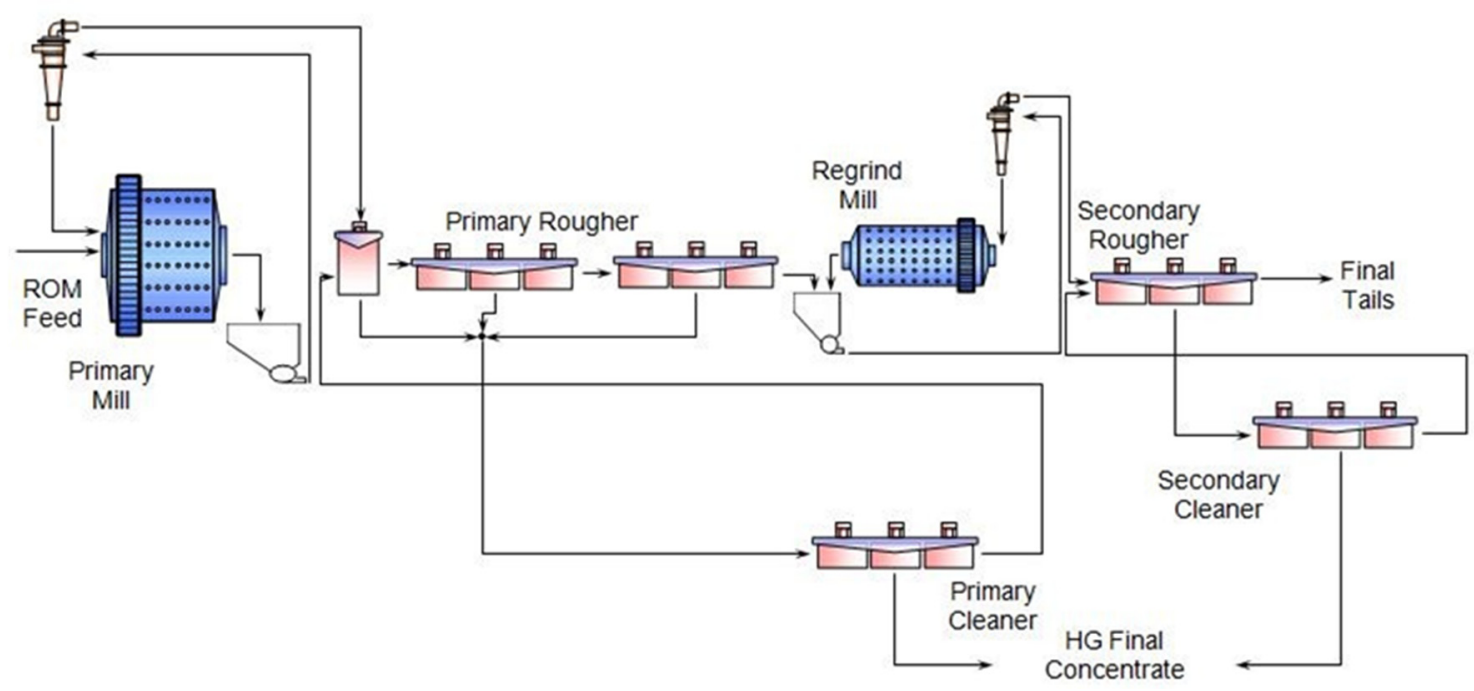

Figure 1. Typical MF2 circuit used in treatment of PGMs in Merensky, Upper Group Chromitite No.2 (UG2), and Platreef ores [7].

These improved processes are aimed at managing the problem of increasing liberation while not excessively grinding finer. As has been shown by Jameson [8], large particles with a high \% surface liberation are able to float as fast as small particles with a lower $\%$ surface liberation.

In a study of the effect of milling circuits for a UG2 ore, it has been shown that on a size-by-size basis, the inclusion of additional mill-float stages results in increased PGM recovery for all size classes, and interestingly, the highest recoveries were achieved in the finest size fraction [9]. This study also showed that liberation of PGM particles in the very fine $-10 \mu \mathrm{m}$ fraction, rather than overgrinding, was the dominant factor at this very fine grind and that fine, liberated particles are more floatable than locked or partially liberated particles in the typically optimum size range (e.g., 38-75 $\mu \mathrm{m}$ ). Such observations emphasize the critical importance of identifying the degree of liberation in various stages of the circuit rather than the particle size. It was proposed that liberation of valuable minerals was more efficient under attrition breakage than impact breakage in the finest size fraction and thus stirred milling proved more efficient at liberating valuable minerals in the finest size fraction but still had the potential to result in over-grinding of liberated particles.

Excessively fine grinding may lead to higher chromite recoveries, which is known to be via entrainment. This is problematic since it is necessary to ensure that the chromite concentration in the concentrate is less than $\approx 3 \%$ so that it does not negatively impact the downstream smelting process. It has been observed that increasing both solids percentage and frother dosage resulted in a non-selective increase in solids recovery owing to entrainment which is a non-selective mechanism based on the particle size and density as well as the water recovery to the concentrate [10].

A further problem when considering fine particle flotation is that the large specific surface area of fine particles increases the amount of reagent that can adsorb at the surface. Thus, a large proportion of the reagent is consumed by the very fine particles. When present in limited amount, there may not be enough reagent available to float the larger particles, which results in decreased recovery. Moreover, especially in the case of sulphide minerals such as those associated with PGMs, rapid oxidation of the mineral might occur, rendering the mineral non-floatable under the conditions used for their flotation.

The present paper reviews the challenges arising from the presence of fines in the processing of PGM ores. These relate to the importance of optimising liberation in comminution circuits as indicated by the mineralogy of the flotation feed and then the management of the gangue minerals including siliceous minerals and chromite in these circuits by using various circuit configurations as well as reagent suites. Finally, the problems created by fines in terms of rheological effects and slime coatings are considered. 


\section{Mineralogy}

In South Africa, platinum group elements (PGEs) are concentrated within the Bushveld Igneous Complex (BIC) (Figure 2).

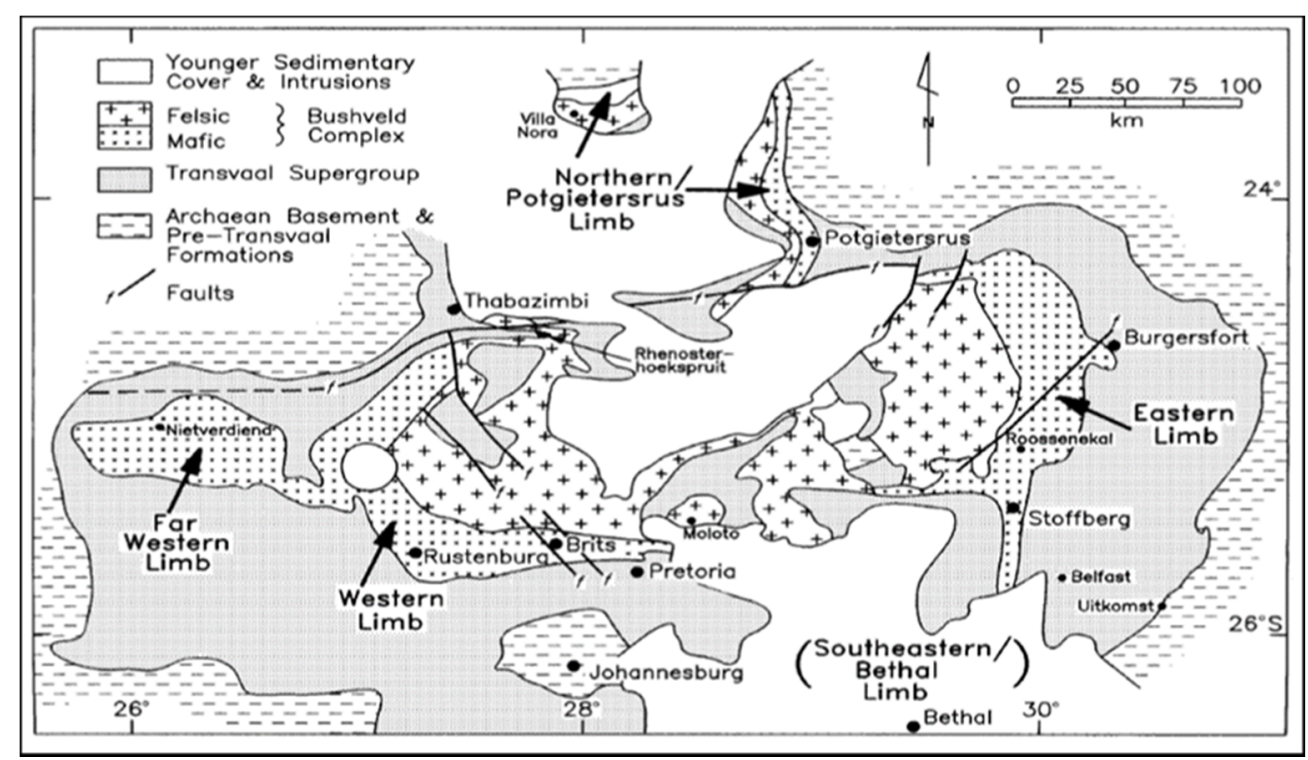

Figure 2. Diagrammatic map of the Bushveld Igneous Complex giving the geographical locations of the western, eastern, and northern limbs [11].

The three main PGE reefs in the BIC are Merensky, UG2, and Platreef. Currently, UG2 and Platreef have become the primary source of PGE production [9,12]. The Merensky, UG2, and Platreef of the BIC contain about $75 \%$ and $50 \%$ of the world's reserves of platinum $(\mathrm{Pt})$ and palladium $(\mathrm{Pd})$, respectively [13,14].

The Merensky Reef is located in the western limb of the BIC. The rock-forming silicate gangue mineralogy of the Merensky Reef is predominantly orthopyroxene, plagioclase feldspar, pyroxene, phlogopite, and occasionally olivine. Secondary minerals present include talc, serpentine, chlorite, and magnetite. The base metal sulphides (BMS) are predominantly pyrrhotite, pentlandite, chalcopyrite with trace amounts of millerite, troilite, pyrite, and cubanite. The primary platinum group minerals (PGM) in the Merensky Reef are cooperite $(\mathrm{PtS})$, braggite $((\mathrm{Pt}, \mathrm{Pd}) \mathrm{NiS})$, sperrylite $\left(\mathrm{PtAs}_{2}\right)$, and PGE alloys. While minerals such as laurite $\left(\mathrm{RuS}_{2}\right)$ can also be abundant. Typical PGE grades in the Merensky Reef are about $3-8 \mathrm{~g} / \mathrm{t}[15,16]$.

The UG2 Reef is composed of the gangue mineral chromite with lesser silicate minerals, i.e., pyroxene and plagioclase [17]. A platiniferous chromitite layer exists, which varies from 30 to $55 \%$, depending on the location within theBIC and the $\mathrm{Cr}_{2} \mathrm{O}_{3}$ content of the reef. Other minor minerals include silicates (phlogopite and biotite), oxides (ilmenite, rutile, and magnetite), and BMS. Secondary minerals are constituted of quartz, serpentine, and talc [15]. PGE grades range between 4 and $7 \mathrm{~g} / \mathrm{t}$ on average and vary by location. The PGMs in the UG2 Reef are generally characterised by the abundant PGE sulphides; laurite $\left(\mathrm{RuS}_{2}\right)$, cooperite $(\mathrm{PtS})$, braggite $((\mathrm{Pt}, \mathrm{Pd}) \mathrm{NiS})$, and an unnamed PtRhCuS $[15,16]$.

The Platreef, north of Mokopane, is located in the northern limb of the BIC. The reef is a complex assemblage of different rock types with pyroxenites, serpentinites, and calc-silicates being the most abundant. Base metal mineralisation and platinum group element (PGE) concentrations are found to be highly irregular, both in value as well as in distribution [15]. The predominant PGMs in the mined area of the Platreef are the PGE tellurides, alloys, arsenides, and sulphides. Typical PGE grades are $2-5 \mathrm{~g} / \mathrm{t}$. The Pt and $\mathrm{Pd}$ tellurides contribute between $30 \%$ and $40 \%$ of the PGMs present in the Platreef ore followed by the alloys $(26 \%)$, arsenides $(21 \%)$, and sulphides $(19 \%)[15,16,18]$. Typical 
compositions and mineralisation of the ore types found in the Bushveld-type rocks are shown in Tables 1-3 [19,20].

Table 1. Typical bulk composition of Merensky, UG2, and Platreef ores.

\begin{tabular}{cccc}
\hline \multirow{2}{*}{ Mineral Name } & Merensky Reef & UG2 Reef & Platreef \\
\cline { 2 - 4 } & \multicolumn{3}{c}{ Volume $\%$} \\
\hline Pyroxene & $55-60$ & $15-30$ & $30-40$ \\
Feldspar & $30-40$ & $3-9$ & 18 \\
Chromite & 6 & $50-75$ & - \\
Talc & $<1$ & $<1$ & $<1$ \\
Serpentine & $2-3$ & 1 & 4 \\
Amphibole & $1-2$ & $<1$ & 4 \\
Chlorite & $1-2$ & $<1$ & 1 \\
Mica & $<1$ & $<1$ & 2 \\
BMS & $<1$ & $<1$ & 5 \\
Other ${ }^{*}$ & $1-2$ & $<1$ & \\
\hline
\end{tabular}

* Other minerals are mainly other silicates, Fe-oxides, and carbonates.

Table 2. Base Metal Sulphides (BMS) Mineralisation of Merensky, UG2, and Platreef ores.

\begin{tabular}{cccc}
\hline \multirow{2}{*}{ Minerals } & Merensky Reef & UG2 Reef & Platreef \\
\cline { 2 - 4 } & & Volume $\%$ & \\
\hline Pentlandite & 35 & $44-52$ & 27 \\
Pyrrhotite & 46 & $26-35$ & 52 \\
Chalcopyrite & 20 & 21 & 19 \\
\hline
\end{tabular}

Table 3. Platinum Group Metal (PGM) Mineralisation of Merensky, UG2, and Platreef ores.

\begin{tabular}{|c|c|c|c|c|}
\hline \multirow{2}{*}{ Class } & \multirow{2}{*}{ Minerals } & Merensky Reef & UG2 Reef & Platreef \\
\hline & & \multicolumn{3}{|c|}{ Volume \% } \\
\hline \multirow{3}{*}{ PGM Alloys } & Ferroplatinum & & & \\
\hline & $\begin{array}{l}\text { Pt Alloy } \\
\text { Pd Alloy }\end{array}$ & 40 & 40 & $11-30$ \\
\hline & Electrum (Au) & 2 & 0.2 & 3 \\
\hline \multirow[t]{2}{*}{ Arsenides } & $\begin{array}{l}\text { Pt-arsenides } \\
\text { Pd-arsenides }\end{array}$ & 4 & $0.1-1$ & $1-20$ \\
\hline & PGE-sulphurarsenides & 3 & $0.8-7$ & $16-35$ \\
\hline PGM sulphides & $\begin{array}{c}\text { PtPd-sulphide } \\
\text { Pt-sulphide } \\
\text { PtRh-sulphide }\end{array}$ & 16 & $40-60$ & $1-7$ \\
\hline Tellurides & $\begin{array}{l}\text { Pt-tellurides } \\
\text { Pd-tellurides }\end{array}$ & 35 & $0.5-5$ & $20-50$ \\
\hline
\end{tabular}

Prior to separation by flotation, the liberation of the economic minerals from the waste minerals is necessary to ensure selective separation. This is achieved by a series of comminution stages, crushing, grinding, and classification [21]. Both the UG2 and Platreef ores contain a larger proportion of fine grained PGMs in association with gangue minerals. For example, PGM grain size in UG2 is typically $<10 \mu \mathrm{m}$. Flotation is less effective if the value minerals are not fully liberated, while flotation may be impossible if the valuable minerals are completely enclosed in gangue silicates, unliberated [12]. Pease et al. [5,22] have shown that PGM grain size is ultra-fine $(<10 \mu \mathrm{m})$ in UG2 ores. The PGMs are associated with the silicates and sulphides, as opposed to the chromite which has particles that are larger $(200 \mu \mathrm{m})$ and denser. Middling streams had a median overall grain size of 
$20 \mu \mathrm{m}$ and PGM grain size of $3 \mu \mathrm{m}$. The PGMs were found to be mostly locked in silicate minerals or on the grain boundaries of silicates and BMS.

Following liberation by comminution, froth flotation is the primary process for mineral separation. Typically, a 1-5\% reduction in mass of the original ore flotation feed is attained in this step [12]. UG2 and Platreef are metallurgically more complex and difficult to process than Merensky, owing to their mineralogy, finer grinds, and more complex circuit designs required to achieve suitable extractions and product grades to be smelted [12]. The key to energy efficiency and improved extraction metallurgy lies in the exploitation of the mineralogy of the ores. Reducing the size of the ore particles to liberate the valuable minerals is highly energy intensive [23], and therefore complete liberation of the valuable minerals from the gangue is not an economically viable practice. An important contributor to the overall recovery achieved during flotation is the recovery of the unliberated (locked) and partially liberated (composite) particles.

\section{Comminution}

As indicated in the introductory section, the comminution technologies and circuits used in mineral processing play an important role in the management of the recovery of fines and these must address the optimisation of liberation without a further increase in the amount of ultra-fines in the flotation circuit feed. Comminution circuits in the PGM industry have generally comprised a MF2 (mill-float-mill-float) circuit as referred to above. The MF2 configuration is comprised of two rougher flotation stages and a regrind mill between the rougher banks. This stage-wise collection of concentrate targets the relatively coarse BMS and fine platinum sulphide minerals in separate circuits. Thus, the over-grinding of both the valuable minerals and chromite/gangue is minimised [9]. However, both the UG2 and Platreef ores have "more difficult" complex mineralogy with higher proportions of fine grained PGMs $(<10 \mu \mathrm{m})$ and flotation is less effective when the valuable minerals are only partially liberated and flotation may be impossible if the valuable minerals are locked in the silicate gangue [12,24,25]. The metallurgical effect on recovery for these "difficult" ores is therefore sensitive to the target grind. Further, $80 \%$ passing $75 \mu \mathrm{m}$ for Platreef is the defined operating parameter at the Anglo American Platinum. However, work has been in progress in recent years, utilizing ultra-fine grinding technology to target a grind of $80 \%$ passing $53 \mu \mathrm{m}$ has shown improvements which are economically beneficial. Ore zones of poor metallurgical performance appear to contain higher amounts of very fine composite silicate/PGM particles, which therefore require finer grinding to liberate for recovery by flotation [26].

Typical primary milling circuits employ Run-of-Mine (ROM) mills. ROM mills include ball, semi-autogenous (SAG), and fully autogenous (FAG) mills [12]. In recent years, an alternative in the primary comminution circuit, the high-pressure grinding roll (HPGR) technology has found its place. With consideration for the global rise in energy costs, HPGR installations have become more prominent, especially in applications where the ore types were harder, such as the Platreef. Innovative flowsheets were proposed by Rule et al. [12] and by Morley [27] which have resulted in significantly increased energy savings. Chapman et al. [28] discussed the results obtained on the impact of different comminution procedures on the flotation of PGMs. The PGE ore showed preferential liberation of platinum when the HPGR was used, compared to the equivalent cone-crushed material. Significant amounts of the value mineral were reported to the finer size fraction. These results indicated, however, that despite greater liberation at equivalent grain size, HPGR did not improve flotation performance, perhaps due to a slime coating problem which could be addressed by sending the fine material straight to the flotation circuit and by passing any further milling. The advantage of HPGR technology compared to classical routes is reduced energy consumption. HPGRs do not need steel grinding media and throughput is less impacted by changes in ore hardness. Therefore, HPGR could prove economically beneficial when considering the variability in ore hardness [29]. Micro-cracking is a further advantage of using an HPGR. Daniel [30] showed that micro-cracking was 
present when ore was ground in the HPGR. Micro-cracks reduce the Bond ball mill work index of $10-25 \%$, when compared with the product from a tertiary cone crusher $[29,31,32]$ and that the HPGR is likely to result in weaker coarser particles, owing to microcracking, and intact fines.

In the past, the secondary milling of UG2 ore was conducted with ball mills. However, in order to improve the liberation of the valuable minerals, IsaMills ${ }^{\mathrm{TM}}$ (Glencore, Brisbane, Australia) have been introduced to the secondary milling circuit [12]. The IsaMilll ${ }^{\mathrm{TM}}$ is a horizontal stirred mill, with a high energy density and fine, inert grinding media, specifically intended for the effective liberation of the very fine, valuable PGMs [5]. Isamills had been operating at Mt ISA in Australia for several years and after IP issues had been resolved, AngloPlatinum decided to integrate this technology into their PGM circuits as they offered significant energy savings over ball milling. Overgrinding is a consideration when using the IsaMilll ${ }^{\mathrm{TM}}$ owing to the high energy density, this is particularly so for the UG2 chromite. Chromite can accumulate in the IsaMill ${ }^{\mathrm{TM}}$, impacting grinding efficiency and may result in unplanned stoppages. Rule [12] found that by allowing a chromite rich stream from bypassing the IsaMilll ${ }^{\mathrm{TM}}$, the overgrinding of chromite could be avoided. Stirred mills have found their place within the UG2 cleaning circuits. According to Rule [12], the benefits of fine grinding in the cleaning circuit are the inert grinding environment, high intensity attrition and improved liberation and these result in improved recoveries and grades. Pease et al. [22] also reported that the use of electrochemically inert grinding media at plant scale increased the recovery of fine sulphide mineral particles. Since the addition of mainstream regrind circuits or mainstream inert grinding (MIG) stirred milling applications have been implemented, Anglo American Platinum Concentrator plants, UG2 recoveries have increased by more than $5 \%$ at the two main production units, viz. the Rustenburg and Amandelbult mining sites. This is one of the largest step change increases in the operations' history. Further flow-sheet modifications and improvements well guided by process mineralogical information are expected in the next decade. Figure 3 shows two applications for IsaMilll ${ }^{\mathrm{TM}}$; MIG and ultra-fine grinding (UFG) on a typical PGM circuit $[24,33,34]$.

Mainstream Inert Grinding (MIG) is designed to improve recoveries by optimising liberation in an 'inert' media environment

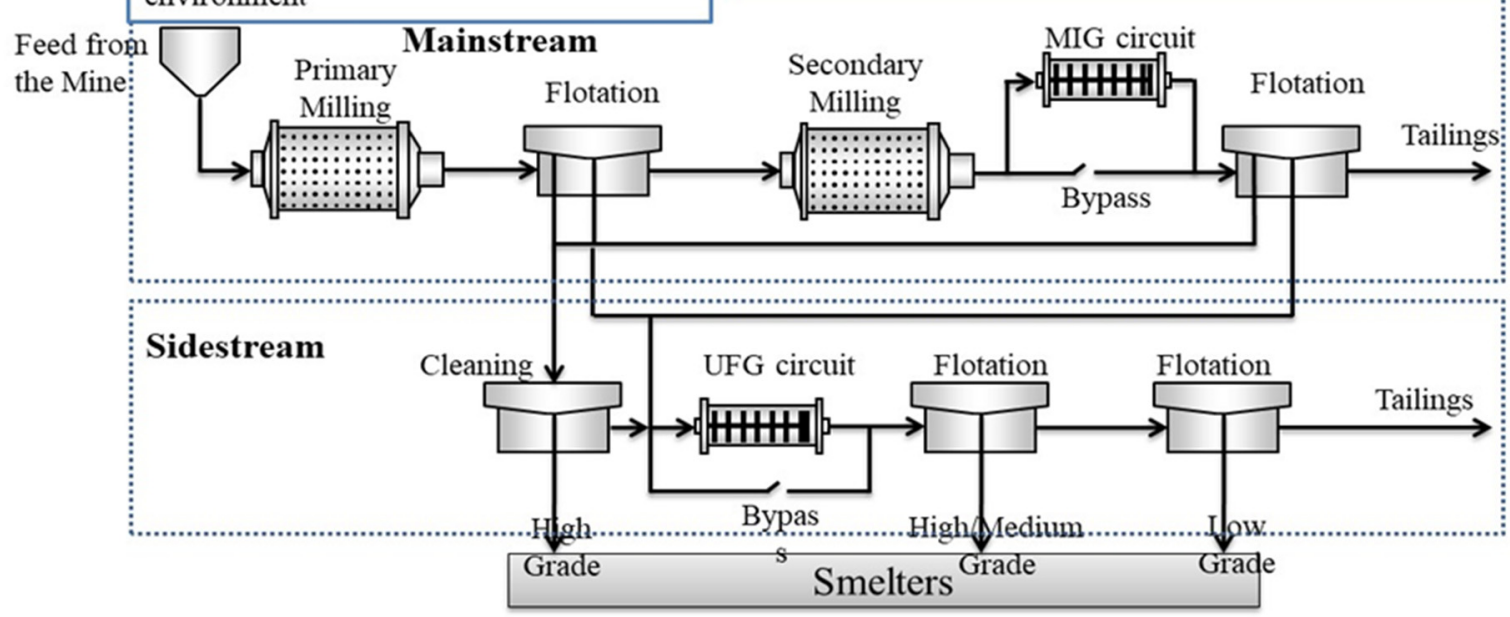

Figure 3. The application of IsaMill1 ${ }^{\mathrm{TM}}$ technology in the concentrator flowsheet $[33,34]$.

It is also important to note the critical role of efficient classification in comminution circuits since this can play a major role in reducing overgrinding and limiting the production of fine particles smaller than the required liberation size [35]. Rule and Schouwstra [25] have discussed the future outlook for PGM concentrators as well as the obstacles facing 
the industry. They noted that the PGM industry had adopted significant new technologies in the concentrator flow sheet design in the last decade. The main drivers for this were as a result of a major switch to UG2 and Platreef ore types, declining plant feed grades, and PGM recovery which has become more difficult to achieve with known technology due to more complex and difficult mineralogy. Finer grinding for better liberation and progressively higher power costs are being fueled by the PGM market dynamics.

\section{Flotation}

Flotation, a well-known selective separation process, is applied to the separation of different minerals from each other. The process takes advantage of the differences in physico-chemical surface properties of minerals within an ore. Decreasing ore reserves necessitates the increased exploitation of low-grade ores and ores with fine intergrowths. In general, these ores are more difficult to process and they often require fine grinding to liberate the valuable minerals so as to increase the valuable minerals recovery as well as the concentrate grade. In this context, the interest in technological steps to improve the flotation recovery of fine particles has significantly increased. The role that particle size plays in froth flotation is complex. Literature suggests that there is an optimum particle size for flotation which is a function of size and degree of liberation $[5,22,36,37]$. As referred to above, Jameson [8] has shown that large particles with a high \% surface liberation are able to float as fast as small particles with a lower \% surface liberation, emphasizing again the importance of careful management of the comminution circuit and importance of using modern mineralogical techniques such as QEMSCAN (Quantitative Evaluation of Materials by Scanning Electron Microscopy) to investigate the degree of liberation of material entering the various stages of the flotation circuit. While increasing particle size and increasing hydrophobicity/liberation improves the probability of attachment, increasing particle size also increases the probability of detachment as liberation decreases [38-40].

In a froth flotation system, particles may enter the froth phase by either true flotation or by mechanical means, such as entrainment or entrapment. While true flotation is selective and involves the attachment of a hydrophobic particle to an air bubble, the other mechanisms are non-selective and mostly depend on particle size and the hydrodynamics of the flotation cell [41,42]. Gaudin et al. [43] demonstrated that different sized particles have different flotation character. The influence of particle size on the recovery rate of minerals has been extensively investigated (e.g., [1,2,44-49]). The reasons why the introduction fine particles are problematic in terms of recovery by flotation are mainly due to their low mass and large surface area which results in factors such as low particle momentum, low probability of bubble-particle collision, heterocoagulation, high consumption of reagent, collector non-selectivity, excessive froth stability, entrainment of fines, high dissolution rate in water, high pulp viscosity, and slimes coating all of which affect the recovery and grade of the valuable minerals. A schematic diagram of the parameters affecting fine particle flotation is shown in Figure 4. Floatability varies depending on the size range of the mineral. Floatability is also dependent upon the type of flotation cell, e.g., laboratory batch flotation or industrial flotation $[5,22]$.

To overcome the difficulties in flotation of fine particles, several flotation technologies, which intend to increase bubble-particle collision efficiency by either decreasing bubble size or increasing particle size, have been developed. However, many of the processes are non-selective and selectivity is essential in the minerals processing industry. A laboratory flotation study [3] carried out on a barren Norite sample from the Merensky Reef and a synthetic mineral, moncheite $\left(\mathrm{PtTe}_{2}\right)$, showed that the moncheite particle size has a significant impact on flotation. Coarse particles $(-53+25 \mu \mathrm{m})$ showed the highest $\mathrm{Pt}$ flotation kinetics and overall recoveries while the $-5 \mu \mathrm{m}$ size fraction of moncheite gave the lowest flotation rate and recoveries. These results correlate with other findings reported in the literature (e.g., [50]). In addition, the data showed that an increased collector dosage enhanced the flotation rate of the $-5 \mu \mathrm{m}$ size fraction of moncheite when compared to a lower collector dosage. The good Pt recovery results obtained for the $-5 \mu \mathrm{m}$ moncheite 
size fraction at the higher collector dosage correlated with the findings in literature where fine particles require higher reagent dosages due to their higher surface area per unit mass $[37,50,51]$.

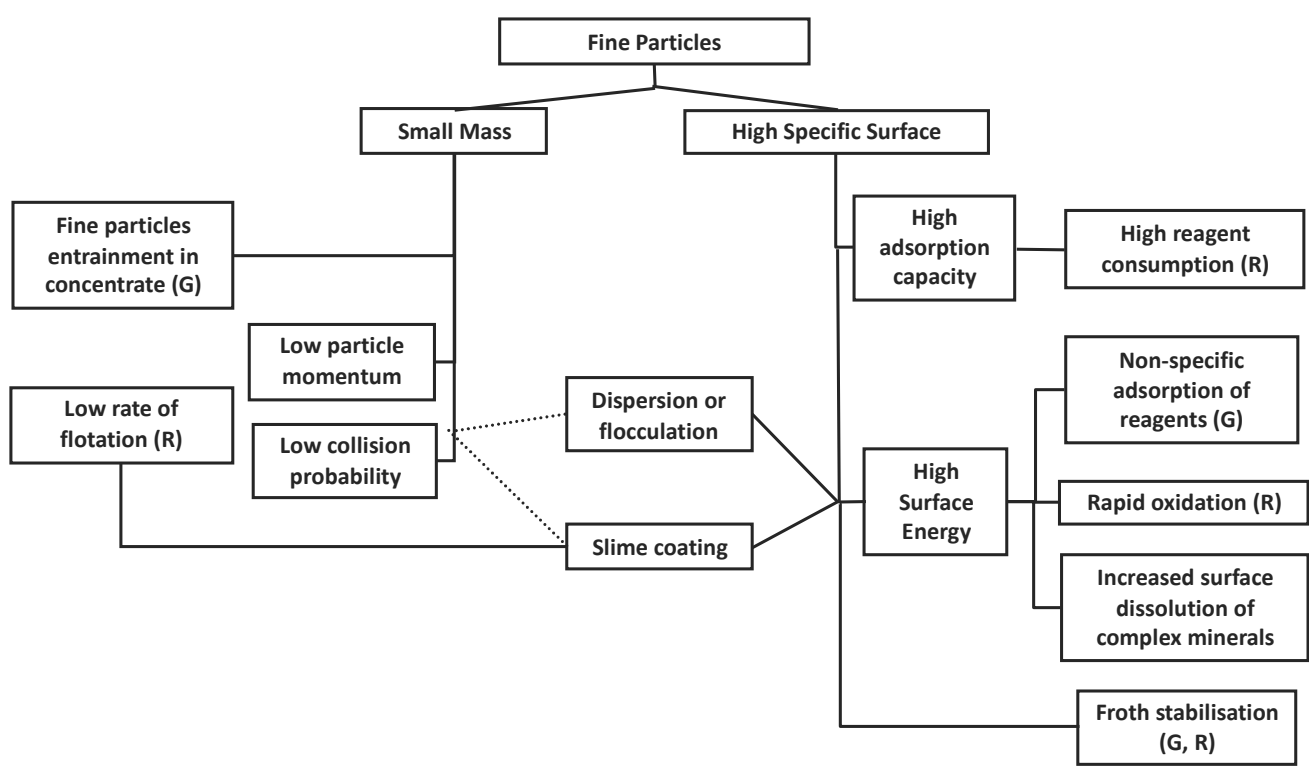

Figure 4. Factors affecting fine particle flotation $[5,22]$.

Higher energy input during laboratory flotation also increased the rate of flotation of the $-5 \mu \mathrm{m}$ size range, at a lower concentrate grade, when compared to a lower impeller speed. It was reported [52] that more favourable Pt kinetics flotation was observed at higher impeller speeds when floating ultrafine PGEs $(-5 \mu \mathrm{m}$ moncheite) and this was attributed to high power inputs, or highly turbulent contacting, improving the rate of flotation of fine particles. At constant air flow, the bubble size decreases when power intensity is increased, and this will also lead to improved particle-bubble attachment, thus improving the fines recovery. However, as will be noted below, it is necessary to maintain a careful balance between power input and bubble size. Matis et al. [53] showed that a smaller bubble size is required when floating fines to maintain a suitable probability of collision. Feng and Aldrich [49] noted that fine particles reported to the concentrate mainly by entrainment and this phenomenon is dealt with below. High bubble loading and high froth stability was observed for fine particles compared to the coarse and medium fractions. However, medium sized particles gave better flotation results. Small and stable bubbles were observed when floating medium sized particles. It was concluded that good results obtained were also influenced by the froth structure.

Design principles for good fines flotation according to Pease et al. [5,22] incorporate a staged grind-float performance. It is important to note that Figure $5 \mathrm{a}$ assumes that a wide range of hydrophobic particle sizes are being floated, while the same recovery profile remains and the optimum size fraction shifts depending on the size range of the particles present in the system (Figure 5b) $[5,22,54]$. It is therefore possible to control the flotation of fine particles by controlling the particle size distribution being floated. If the size range is narrowed towards the fine particle range, more fines will be recovered. This is the basis for the use of MF2 or MF3 circuits, referred to above, which enable the stagewise recovery of different classes of particle sizes. 
Conventional View - "fines do not float"

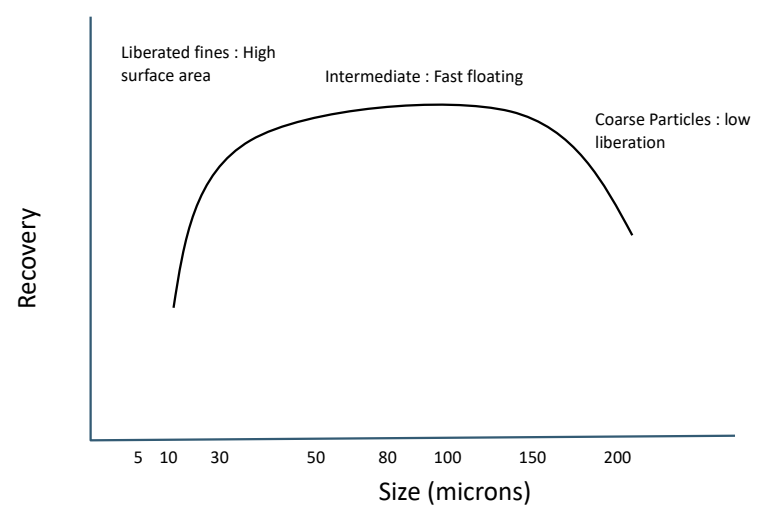

(a)

\section{Conceptual staged grind-float performance}

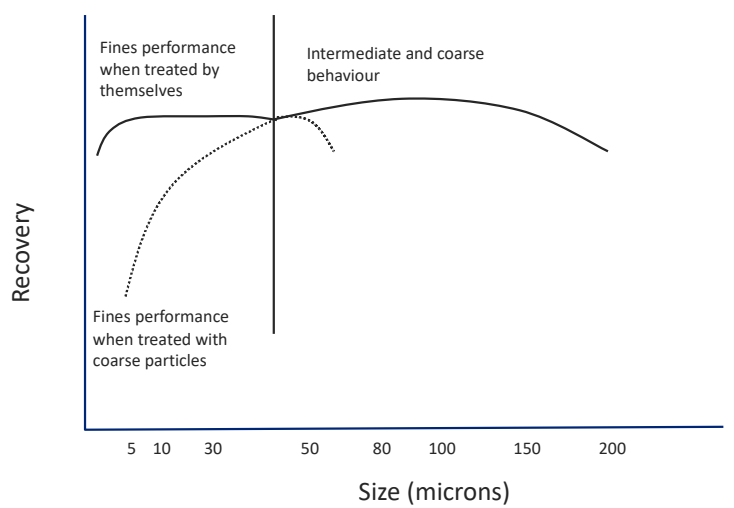

(b)

Figure 5. (a) Recovery as a function of particle size, showing three defined regions. (b) Recovery of fines when treated separately from the other size fractions $[5,22,54]$.

With respect to reagents when treating fines, Corin et al. [55] showed that each collector performs a different action and therefore may target different sized particles. It was shown that when dithiophosphate (DTP) is used as a co-collector with sodium isobutyl xanthate (SIBX), the recovery of $<10 \mu \mathrm{m}$ particles can be increased. Shackleton et al. [3] also noted that as collector dosage is increased, an increase in recovery of particles in the $<5 \mu \mathrm{m}$ size fraction is seen. These observations are of particular importance in the flotation of PGMs since a significant amount of the valuable minerals such as $\mathrm{Pt}$ and $\mathrm{Pd}$ report to such size fractions. The use of DTP increased the recovery of Pt and more so Pd. A case study conducted on a Platreef ore [20], in which collectors containing [SIBX + DTP mixtures] and [SIBX + DTC mixtures], each of varying ratios, were evaluated, showed that [SIBX + DTP mixtures] specifically targeted the PGM sulph-antimonides and sulphur-aresenides while [SIBX + DTC mixtures] targeted the platinum sulphide and telluride minerals. More importantly for the middling's material, the [SIBX + DTP mixtures] reagent regime targeted the PGE silicates while the [SIBX + DTC mixtures] targeted the PGE sulphides. Similar trends were observed for Merensky and UG2 ores. These results have shown a strong correlation between PGE mineral type and collector type.

Froth stability is significantly impacted by particle size. Fine hydrophilic particles have been noted to render bubbles less likely to coalescence and thereby promoting a stable froth, leading to an increase in fine particle recovery [56,57]. Finely sized particles can become entrapped between two adjacent bubbles which can either enhance or reduce froth stability dependent upon the particle properties: shape, roughness, concentration, hydrophobicity, and the thin film formation rate [58]. The relationship between froth stability and entrainment is discussed in the next section.

The use of novel cell technology to enhance fines recovery has also recently enjoyed considerable interest. In a recent study using a pilot-scale oscillating grid column (OGC) investigating PGM flotation in a Platreef ore, it was concluded that when using normal flotation-size bubbles, increasing power input increases the rate of flotation of finer particles $(-25 \mu \mathrm{m})$ and an optimum rate of flotation of intermediate $(+25-53 \mu \mathrm{m})$ and coarse particles $(+53-75 \mu \mathrm{m})$. However, for microbubbles, increasing power input leads to a decrease in the rate of flotation for all particle sizes. It was found that optimum conditions for fine particle PGM flotation require microbubbles at low power inputs or normal bubbles at high power inputs [59].

\section{Entrainment}

The degree of entrainment of mineral particles, defined as the ratio of the recovery by entrainment to the recovery of water, is well known to increase exponentially with 
decreasing particle size [42]. The size at which particles become entrained is dependent on their density and shape, but as a rule occurs at about $<50 \mu \mathrm{m}$ [60]. Since PGM flotation requires that particles are ground very fine in order to liberate them, particularly in the secondary circuit, entrainment is problematic in PGM flotation. Particles feeding the secondary roughers may be anywhere between $40 \%$ to $80 \%$ less than $50 \mu \mathrm{m}$. This means that up to $80 \%$ of particles could theoretically be entrained to some degree. Lima et al. [61] showed the dramatic effect that particle size has on the degree of entrainment. For example, the hematite degree of entrainment of particles increased by about eight times when the mean particle size decreased from 45 to $25 \mu \mathrm{m}$. Considering that PGM grain sizes average about $7 \mu \mathrm{m}$, since liberation requires a very fine grind, it is likely that this will result in significant degree of entrainment. Obviously, entrainment recovery dilutes the grade of the concentrate and should be controlled in order to improve grade and reduce mass pull. However, it is especially important in the processing of UG2 ores, where about $70 \%$ (by mass) of the feed consists of chromite which is problematic since in the downstream smelting of PGM ores, chromite needs to be kept below about $2.5 \%$ in the feed to the furnace [62].

The amount of material recovered by entrainment to the concentrate depends not only on the particle size but on the operation of the cells and the circuit. Higher air flow rates, frother concentrations, pulp solids concentration, and shallow froth depths all contribute to higher recovery by entrainment. This was illustrated in a study of the interactive effects of dosage of frother and depressant, air flow rate, and froth height on a UG2 ore [63]. This showed that the superficial gas velocity had the greatest effect on recovery by entrainment of the chromite, with froth height and frother concentration being the other two significant factors. The study was done at froth heights ranging between 180 and $300 \mathrm{~mm}$ and superficial gas velocities between 0.5 and $1.5 \mathrm{~cm} / \mathrm{s}$ in order to mimic standard froth residence times under plant conditions. Results from tests conducted in a modified, continuous laboratory flotation cell with $150 \mathrm{~mm}$ froth depth have shown that between $50 \%$ and $70 \%$ of total gangue recovered to the concentrate did so as a result of entrainment. This is even though much of the pyroxene is recovered by true flotation due to finely disseminated talc within the pyroxene [64].

Hay and Roy [62] illustrated the effects of the head grade (or solids concentration) on recovery by entrainment by showing significant differences in chromite recovery between different head grades. $\mathrm{Cr}_{2} \mathrm{O}_{3}$ head grades of between $25-31 \%$ produced recoveries of up to $18 \%$, whereas head grades of between $14-20 \%$ only produced recoveries of up to about $6 \%$. This was also well illustrated by Valenta [10] who showed that solids recovery by entrainment increased fourfold with a threefold increase in pulp solids concentration. This corresponded with 2.5 times reduction in PGM grade, which was attributed to increased gangue entrainment. This shows the benefits of operating at lower percent solids, which is also carried through to improvements in valuable mineral recovery due to improved rheological behaviour $[65,66]$. Obviously, this comes with a loss in residence time or throughput and these different requirements need to be balanced.

Circuit design and residence time is critical in limiting recovery by entrainment of fine particles. Many plants employ multiple stages of cleaning [10], while others bypass cleaning altogether and send rougher concentrates directly to final concentrate. This is unusual and detrimental to grade, as there is usually at least one stage of cleaning to allow for removal of entrained gangue. Another method to deal with the removal of fines by entrainment is froth washing [5,22]. However, this is seldom used in the PGM industry due to the potential for loss of PGMs arising from such treatment. Another method of limiting entrainment, which is utilised for different ore types, is the use of column flotation cells. These cells have deep froths which allow for long froth drainage times, thus limiting recovery by entrainment. In laboratory scale column flotation tests, it was found that froth height had little effect on the water or solids recoveries or on the grade of chromite in the concentrate possibly due to the density of chromite particles [67]. However, columns are seldom used in the PGM industry presumably due to the low energy input which may limit 
bubble particle collision efficiency for the very fine particle sizes produced during PGM liberation and the inability to maintain the deep froths required for column cells. There are a few examples of column cells within the PGM industry, one of which is discussed by Hay [68]. Two column cells were installed as final cleaners on a PGM plant treating UG2 ore and this reduced the $\mathrm{Cr}_{2} \mathrm{O}_{3}$ grade from $4.0 \%$ to $2.2 \%$. There was, apparently, no difficulty in maintaining the deep froths required. This is, perhaps, not surprising because, although there are very little floating valuable minerals in UG2 ores, there are relatively large amounts of floatable gangue with which to stabilise the froth. The external sparger on the column cell was driven by a recirculation pump, imparting energy for improved bubble-particle collision, which improved PGM recovery by $6 \%$.

Residence time is another critical factor in limiting recovery by entrainment in fine particle PGM flotation. It is crucial to match the residence time of each bank to the kinetics of the valuable mineral flotation. The residence time of the bank should be just long enough to achieve the desired valuable mineral recovery and not so long as to allow prolonged recovery of entrained and slow floating gangue species. This is usually achieved in the rougher banks but may be very poor in cleaner banks. This is well illustrated by Lima et al. [61] in a discussion of matching the residence time of banks to the relative kinetics of quartz and hematite, which is analogous to the PGM and chromite recovery by true flotation (quartz and PGMs) and entrainment (hematite and chromite). It is worth noting that there are options such as the use of gravity concentration techniques to manage chromite recovery $[7,69]$.

As mentioned above, the abundance of fine particles in PGM flotation processing has an impact on the froth structure. Achaye et al. [70] showed that there is an exponential increase in froth stability for feed particle sizes below about $50 \mu \mathrm{m}$. This was driven, in large part, by the increase in particle surface area recovered to the froth by entrainment, which resulted in a more viscous and more stable froth. This will be true for PGM processing where much of the feed, particularly after secondary and tertiary grinding, is less than $50 \mu \mathrm{m}$ in size. This drives a circular dependence, where more fines lead to more entrainment, which produces a more stable froth that, in turn, leads to more entrainment.

Reagents, of course, influence both froth stability and entrainment. McFadzean et al. [71] showed that mixtures of alcohol and polypropylene glycol frothers could improve both recovery and grade compared to the sum of their constituents in a UG2 ore. The froth effects were decoupled from the pulp effects to explain this. It was found that the frother blends could improve froth stability while also reducing entrainment. This resulted in improved recovery, due to improved froth stability and improved grade due to less entrainment. Another study by Nyabeze and McFadzean [72] showed that the use of $\mathrm{CuSO}_{4}$ had a similar effect on the froth and not on the pulp phase recovery, as expected. This showed that the addition of $\mathrm{CuSO}_{4}$ destabilised or improved the drainage effect on both Merensky and UG2 ores. At full scale plant performance this translated to improved PGM grades with very slight decreases in recovery. The difference in degree of entrainment was clear, with lower degrees of entrainment observed in the absence of $\mathrm{CuSO}_{4}$ compared to when $\mathrm{CuSO}_{4}$ was used.

\section{Rheology and Slimes Coatings}

Rheological and slimes coatings problems in PGM flotation are generated from similar causes, mainly through the production of ultrafine phyllosilicate mineral particles during grinding. Although they have similar causes, the mechanisms of their impact in the concentrator circuit are different and they will be dealt with separately below. The methods whereby these detrimental effects can be mitigated does, however, overlap to some extent and will be dealt with in Section 6.3 .

\subsection{Rheology}

Rheology influences the flow of slurry through mills, the separation efficiency of hydrocyclones, the hydrodynamics of flotation cells, the stability/mobility of flotation 
froths, and the dewatering and pumping of slurries [73]. The presence of ultrafine particles has a dominating impact on rheology, particularly at high volumetric solids concentrations. In general, slurries display non-Newtonian behaviour, characterised by a yield stress and a viscosity, both of which increase exponentially with decreasing particle size. However, despite the important influence of particle size and solids concentration on rheology, factors such as particle morphology, mineralogy, and pulp chemistry also have a significant influence. For pulp chemistry, the $\mathrm{pH}$ has a strong influence as it affects the mineral surface charge distribution and the associated aggregation or dispersion of particles. Particle morphology and mineralogy can also have an important influence on slurry rheology. Studies on particle mineralogy and rheology have noted phyllosilicate gangue minerals, particularly swelling clays and serpentine minerals, as major contributors [74,75]. Studies on various platinum ores have shown that rheologically complex behaviour is dependent on the amount of phyllosilicate alteration minerals, with ores such as Platreef and Great Dyke being potentially problematic [76,77].

Rheology has an influence on most of the processing steps on platinum concentrators. For tumbling mills, rheological complexity affects the retardation of grinding within the ultrafine regime [78] and slurry transport through the mill [79]. Rheology is also one of the most important considerations for the performance of ultrafine grinding in stirred mills, such as IsaMills [73]. Rheology has a significant influence on hydrocyclone performance as here the flow behaviour is extremely complex [80]. For flotation, rheological complexity influences flotation cell hydrodynamics which may result in poor gas dispersion [81,82], increased turbulence damping, and lower flotation rates [83]. However, a higher pulp viscosity can improve the stability of bubble-particle aggregates [84]. Rheology also affects the behaviour of flotation froths, such as froth mobility and froth stability. Froth mobility refers to the general motion of the froth while froth stability includes processes occurring within the froth such as bubble bursting and drainage of water and solids. While several studies have attempted to model froth recovery in flotation cells [85-88], only a few have focused on the effect of rheology on froth behaviour [89-93]. Results have indicated that froth properties are correlated with rheological measurements, but the underlying mechanisms are not clear due to the complexity of froth behaviour. Rheological complexity also affects downstream processes such as dewatering, tailings disposal, and storage [73]. Tailings dams are sensitive to rheology as it affects both the rate of settling and the slurry compressibility, potentially resulting in instability [94].

\subsection{Slimes Coatings}

Slimes coatings are the ultrafine (less than $10 \mu \mathrm{m}$ ) gangue mineral particles that coat the surface of valuable minerals. These slimes are generated from the same minerals that create a problematic response in viscosity, the phyllosilicate minerals, which are soft minerals and prone to overgrinding. Slimes are attracted to the surface of the valuable minerals by means of an electrostatic attraction. Shackleton et al. $[95,96]$ measured the zeta potential of sperrylite and moncheite, two common PGM minerals, and found them to be -17 and $-22 \mathrm{mV}$, respectively. Serpentine, talc, and chlorite, three common altered phyllosilicate minerals present in PGM ores, are known to have both positively and negatively charged planes, which can interact electrostatically with the negatively charged PGMs $[97,98]$. This results in poor collector adsorption and increased hydrophilic behaviour of the valuable PGMs.

\subsection{Mitigation of Rheological and Slimes Effects in PGM Flotation}

Both physical and chemical methods can be used to mitigate the effects of complex rheology and slime coatings due to ultrafine particles. While much work has been done on these subjects in other commodities, little work has been done in the PGM industry, which is perhaps surprising, considering the altered phyllosilicates present in many PGM ores.

For rheology, the simplest method of mitigating rheological complexity is to reduce the ultrafine particles generated by more efficient comminution and classification. Operating 
at lower volumetric solids concentrations is also possible in areas such as flotation, but generally not in milling and tailings disposal. Effective gangue management can also be considered by on-going monitoring of the concentrator feed for phyllosilicate mineral content as platinum ores show considerable local geological variation and alteration [77]. If these physical methods are not viable, then chemical methods may be considered, such as changing the pulp $\mathrm{pH}$ or using chemical dispersants and rheology modifiers. These methods generally rely on reducing the interparticle interaction force to promote dispersion [99]. Changing the pulp $\mathrm{pH}$, to promote electrostatic repulsion, is generally not viable on platinum concentrators. The use of grinding aids, such as polyelectrolytes, to improve rheology in mills has been studied for many years due to the high solids concentrations $[100,101]$. However, research on rheology modifiers within the context of flotation is not as extensive but has increased in recent years with the complexity of ores. In general, the use of dispersants and rheology modifiers can aid in the dispersion of the slimes, improve rheology, and thereby improve process efficiency [84,97,102].

For slimes coatings, both physical and chemical investigations have been conducted to mitigate the effects on PGM flotation. Ross et al. [103] investigated the use of a high shear hydrodynamic cavitation device to physically remove slimes from valuable mineral particles. They found that the use of this device significantly improved the grade and recovery of rougher, cleaner, and recleaner feed material for a UG2 tailings retreatment plant. Molifie et al. [97] found that the use of sodium silicate was effective in improving recovery and grade of a PGM ore containing large quantities of serpentine and talc. This study decoupled the various effects of the sodium silicate and found that it had a beneficial effect on reversing the surface charge of the serpentine mineral, thus reducing the electrostatic attraction, as well as reducing viscosity and depressing the naturally floatable talc. There is scope for further investigation of the effects of slimes mitigating factors in PGM flotation.

\section{Conclusions}

This study has reviewed the problems and challenges associated with the presence of fines in the processing of PGMs. In the treatment of such ores, the need to grind to fine particle sizes is probably more important than in the treatment of any other ores due to economic value of the minerals being recovered and hence the need to ensure adequate liberation to optimize recovery. The application of sophisticated mineralogy to quantify the liberation throughout the circuit is of paramount importance. It is critical to ensure that there is a careful design of flotation circuits as well as the need to use novel comminution and flotation devices as well as appropriate reagent suites. Finally, the need to manage the effect of the generation of fines on factors such as entrainment, rheology, and slimes coatings is of critical importance. The paper addresses all these issues and indicates how they are being handled on modern concentrators.

Author Contributions: Writing—original draft preparation, review and editing: K.C.C.; B.J.M.; N.J.S.; C.T.O. All authors have read and agreed to the published version of the manuscript.

Funding: This research received no funding.

Data Availability Statement: Data sharing not applicable.

Acknowledgments: The authors would like to acknowledge numerous valuable contributions to this paper by David Deglon.

Conflicts of Interest: The authors declare no conflict of interest.

\section{References}

1. Trahar, W.J.; Warren, L.J. The floatability of very fine particles-A review. Int. J. Miner. Process. 1976, 3, 103-131. [CrossRef]

2. Fuerstenau, D.W. Fine Particle Flotation. In Fine Particle Processing; Somasundaran, P., Ed.; The American Institute of Mining, Metallurgical and Petroleum Engineers: New York, NY, USA, 1980; pp. 669-705.

3. Shackleton, N.J.; Mokoena, D.M.; Malysiak, V. Fundamental study of fine PGE particle flotation. In Proceedings of the XXVII International Minerals Processing Congress, New Delhi, India, 24-28 September 2012. 
4. Grano, S.R.; Wong, P.; Skinner, W.; Johnson, N.W.; Ralston, J. The effect of autogenous and ball mill grinding on the chemical environment and flotation of the copper ore of Mount ISA Mines Ltd. In Proceedings of the III Latin-American Congress on Froth Flotation, Concepcion, Chile, 20-23 November 1994; pp. 351-388.

5. Pease, J.D.; Curry, D.C.; Young, M.F. Designing flotation circuits for high fines recovery. Miner. Eng. 2006, 19, 831-840. [CrossRef]

6. Rule, C.M.; Plint, N. What will the typical PGM concentrator look like? In Proceedings of the 8th International Comminution Symposium, Comminution'12, Cape Town, South Africa, 17-20 April 2012.

7. Engelbrecht, J. Potential changes in the physical beneficiation processes that can improve the recovery grade or costs for the platinum group metals. In Proceedings of the Fifth International Platinum Conference: A Catalyst for Change 2012, Sun City, South Africa, 19-21 September 2012.

8. Jameson, G.J. The effect of surface liberation and particle size on flotation rate constants. Miner. Eng. 2012, 36-38, 132-137. [CrossRef]

9. Steyn, J.J. Developing a Framework for the Design of the Milling and Rougher Circuits for a Platinum-Bearing UG2 Ore. Ph.D. Thesis, University of Cape Town, Cape Town, South Africa, 2012.

10. Valenta, M.M. Balancing reagent suite to optimize grade and recovery. Miner. Eng. 2007, 20,979-985. [CrossRef]

11. Cawthorn, R.G.; Webb, S.J. Connectivity between western and eastern limbs of the Bushveld Complex. Tectonophysics 2001, 330, 195-209. [CrossRef]

12. Rule, C.M. Energy considerations in the current PGM processing flowsheet utilizing new technologies. J. S. Afr. Inst. Min. Metall. 2008, 108, 30-46.

13. Cawthorn, R.G. Seventy-fifth Anniversary of the Discovery of the Platiniferous Merenskv Reef: The largest platinum deposits in the world. Platin. Met. Rev. 1999, 43, 146.

14. Cawthorn, R.G. The platinum and palladium resources of the bushveld complex. S. Afr. J. Sci. 1999, 95, 48-489.

15. Schouwstra, R.P.; Kinloch, E.D.; Lee, C.A. A short geological review of the Bushveld Complex. Platin. Met. Rev. $2000,44,33-39$.

16. O'Connor, C.; Alexandrova, T. The geological occurrence, mineralogy, and processing by flotation of platinum group minerals (PGMs) in South Africa and Russia. Minerals 2021, 11, 54. [CrossRef]

17. Vermaak, C.F. The Platinum Group Metals: A Global Perspective; Mintek: Randburg, South Africa, 1995 ; p. 247.

18. Shackleton, N.J. Surface Characterization and Flotation Behavior of the Platinum and Palladium Arsenide, Telluride and Sulphide Mineral Species. Ph.D. Thesis, University of Cape Town, Cape Town, South Africa, 2007.

19. Malysiak, V.; Shackleton, N.J. Private, Personal Communication, 2010.

20. Shackleton, N.J.; Malysiak, V.; Theron, E.H.W.; Dicks, P.F. Where chemistry and mineralogy meet during PGE and BMS flotation. In Proceedings of the XXX International Mineral Processing Congress, Cape Town, South Africa, 18-22 April 2021.

21. Napier-Munn, T.J.; Morrell, S.; Morrison, R.D.; Kojovic, T. Mineral Comminution Circuits—Their Operation and Operation; Julius Kruttschnitt Mineral Research Centre: Indooroopilly, Australia, 1996.

22. Pease, J.D.; Curry, D.C.; Barnes, K.E.; Young, M.F.; Rule, C. Transforming flow sheet design with inert grinding media-The IsaMill. In Proceedings of the 38th Annual Meeting of the Canadian Mineral Processors, Ottawa, ON, Canada, 17-19 January 2006; pp. 231-249.

23. Ballantyne, G.; Powell, M.S. Benchmarking comminution energy consumption for the processing of copper and gold ores. Miner. Eng. 2014, 65, 109-114. [CrossRef]

24. Rule, C. Stirred milling-New comminution technology in the PGM industry. In Proceedings of the 4th International Platinum Conference, Platinum in Transition 'Boom or Bust', Sun City, South Africa, 11-14 October 2010.

25. Rule, C.; Schouwstra, R.P. Process mineralogy delivering significant value at anglo platinum concentrator operations. In Proceedings of the 10th International Congress for Applied Mineralogy (ICAM), Trondheim, Norway, 1-5 August 2011; Broekmans, M., Ed.; Springer: Berlin/Heidelberg, Germany, 2012.

26. Humphries, G.; Rule, C.; Wolmarans, E. The development of a process flowsheet for the new Anglo Platinum PPRust north concentrator; incorporating HPGR technology. In Proceedings of the International Platinum Conference 'Platinum Surges Ahead', Sun City, South Africa, 8-12 October 2006; The Southern African Institute of Mining Metallurgy: Johannesburg, South Africa, 2006.

27. Morley, C.T. Plant Layout Considerations for High Pressure Grinding Rolls; Procemin: Santiago, Chile, 2008.

28. Chapman, N.A.; Shackleton, N.J.; Malysiak, V.; O'Connor, C.T. The effect of using different comminution procedures on the flotation of Platinum-Group Minerals. Miner. Eng. 2011, 24, 731-736. [CrossRef]

29. Amelunxen, P.; Meadows, D. Not another HPGR trade-off study! Miner. Metall. Process. 2011, 28, 1-7. [CrossRef]

30. Daniel, M. Energy Efficient Mineral Liberation Using HPGR Technology. Ph.D. Thesis, University of Queensland, Brisbane, Australia, 2007.

31. Patzelt, N.; Klymowsky, R.I.B.; Knecht, J.; Burchardt, E. High-pressure grinding rolls for gold/copper applications. In Advances in Comminution; Kawatra, S.K., Ed.; Society for Mining Metallurgy \& Exploration: Englewood, CO, USA, 2006; pp. 51-68.

32. Ballantyne, G.R.; Hilden, M.; van der Meer, F. Improved characterisation of ball milling energy requirements for HPGR products. Miner. Eng. 2017, 116, 72-81. [CrossRef]

33. Rule, C.M. Stirred milling-New comminution technology in the PGM industry. J. S. Afr. Inst. Min. Metall. 2011, 111, 101-107.

34. Rule, C.M. Stirred milling at Anglo American Platinum. In Proceedings of the International Autogenous Grinding and High Pressure Grinding Roll Technology, Vancouver, BC, Canada, 25-28 September 2011. 
35. Becker, M.; Mainza, A.N.; Powell, M.S.; Bradshaw, D.J.; Knopjes, B. Quantifying the influence of classification with the 3-product cyclone on liberation and recovery of PGMs in UG2 ore. Miner. Eng. 2008, 21, 549-558. [CrossRef]

36. Jowett, A. The formation and disruption particle-bubble aggregates in flotation. In Proceedings of the Fine Particles Processing: International Symposium on Fine Particles Processing, Las Vegas, NV, USA, 24-28 February 1980; American Institute of Mining: New York, NY, USA, 1980; Volume 1, pp. 720-753.

37. Trahar, W. Rational interpretation of the role of particle size in flotation. Int. J. Miner. Process. 1981, 8, 289-327. [CrossRef]

38. Tao, D. Role of bubble size in flotation of coarse and fine particles. Sep. Sci. Technol. 2004, 39, 741-760. [CrossRef]

39. Dai, Z.; Dukhin, S.; Fornasiero, D.; Ralston, J. The inertial hydrodynamic interaction of particles and rising bubbles with mobile surfaces. J. Colloid Interfacial Sci. 1998, 197, 275-292. [CrossRef]

40. Dai, Z.; Fornasiero, D.; Ralston, J. Particle-bubble collision models-A review. Adv. Colloid Interface Sci. 2000, 85, 231-256. [CrossRef]

41. Kirjavainen, V. Review and analysis of factors controlling the mechanical flotation of gangue minerals. Int. J. Miner. Process. 1996, 46, 21-34. [CrossRef]

42. Savassi, O.N.; Alexander, D.J.; Franzidis, J.P.; Manlapig, E.V. An empirical model for entrainment in industrial flotation plants. Miner. Eng. 1998, 11, 243-256. [CrossRef]

43. Gaudin, A.M.; Schuhmann, R., Jr.; Schlechten, A.W. Flotation kinetics, II. The effect of size on the behaviour of galena particles. J. Phys. Chem. 1942, 46, 902-910. [CrossRef]

44. Anthony, R.M.; Kelsall, D.F.; Trahar, W.J. The effect of particle size on the activation and flotation of sphalerite. Proc. Australas. Inst. Min. Metall. 1975, 254, 47-58.

45. Trahar, W.J. The selective flotation of galena from sphalerite with special reference to the effects of particle size. Int. J. Miner. Process. 1976, 3, 151-166. [CrossRef]

46. Jameson, G.J. Physical aspects of fine particle flotation. In Principles of Mineral Flotation. The Wark Symposium; Series 40; Jones, M.H., Woodcock, J.T., Eds.; The Australasian Institute of Mining and Metallurgy: Carlton, Australia, 1984; pp. $215-232$.

47. Subrahmanyam, T.V.; Forssberg, K.S.E. Froth stability, particle entrainment and drainage in flottaion-A review. Int. J. Miner. Process. 1988, 23, 33-53. [CrossRef]

48. Miettinen, T.; Ralston, J.; Fornasiero, D. The limits of fine particle flotation. Miner. Eng. 2010, 23, 420-437. [CrossRef]

49. Farrokhpay, S.; Filippov, L.; Fornasiero, D. Flotation of fine particles: A review. Miner. Process. Extr. Metall. Rev. 2020. [CrossRef]

50. Feng, D.; Aldrich, C. Effect of particle size on flotation performance of complex sulphide ores. Miner. Eng. 1999, 12, 721-731. [CrossRef]

51. Collins, D.N.; Read, A.D. The treatment of slimes. Miner. Sci. Eng. 1971, 3, 19-31.

52. Deglon, D.A. The effect of agitation on the flotation of platinum ores. Miner. Eng. 2005, 18, 839-844. [CrossRef]

53. Matis, K.A.; Gallios, G.P.; Kydros, K.A. Separation of fines by flotation techniques. Sep. Technol. 1993, 3, 76-90. [CrossRef]

54. Pease, J.D.; Young, M.F.; Curry, D.; Johnson, N.W. Improving Fines Recovery by Grinding Finer; MetPlant: Perth, Australia, 2004.

55. Corin, K.C.; Bezuidenhout, J.C.; O'Connor, C.T. The role of dithiophosphate as a co-collector in the flotation of a platinum group mineral ore. Miner. Eng. 2012, 36-38, 100-104. [CrossRef]

56. Schwarz, S. The Relationship between Froth Recovery and Froth Structure. Ph.D. Thesis, Ian Wark Research Institute, Mawson Lakes, Australia, 2004.

57. Szatkowski, M.; Freyburger, W. Kinetics of flotation with fine bubbles. Trans. Inst. Min. Metall. 1985, 94, C61-C70.

58. Ross, V. An investigation of sub-processes in equilibrium froths (1): The mechanisms of detachment and drainage. Int. J. Miner. Process. 1991, 31, 37-50. [CrossRef]

59. Safari, M.; Harris, M.C.; Deglon, D.A. The effect of energy input on the flotation of a platinum ore in a pilot-scale oscillating grid flotation cell. Miner. Eng. 2017, 110, 69-74. [CrossRef]

60. Zheng, X.; Johnson, N.W.; Franzidis, J.P. Modelling of entrainment in industrial flotation cells: Water recovery and degree of entrainment. Miner. Eng. 2006, 19, 1191-1203. [CrossRef]

61. Lima, N.M.; Pinto, T.C.; Tavares, A.C.; Sweet, J. The entrainment effect on the performance of iron ore reverse flotation. Miner. Eng. 2016, 96-97, 53-58. [CrossRef]

62. Hay, M.P.; Roy, R. A case study of optimizing UG2 flotation performance. Part 1: Bench, pilot and plant scale factors which influence Cr2O3 entrainment in UG2 flotation. Miner. Eng. 2010, 23, 855-867. [CrossRef]

63. McFadzean, B.; Pani, S.; Wiese, J.; O' Connor, C.T. The interactive effects of chemical and process parameters on the flotation performance of a UG2 ore. Miner. Eng. 2015, 70, 92-98. [CrossRef]

64. Becker, M.; Harris, P.J.; Wiese, J.G.; Bradshaw, D.J. Mineralogical characterisation of naturally floatable gangue in Merensky Reef ore flotation. Int. J. Miner. Process. 2009, 93, 246-255. [CrossRef]

65. Gao, Y.; Zhang, G.; Wang, M.; Liu, D. The critical role of pulp density on flotation separation of nickel-copper sulfide from fine serpentine. Minerals 2018, 8, 317. [CrossRef]

66. Molifie, A. Investigating the Use of Sodium Silicate to Improve the Flotation Performance of Altered PGE Ores. Ph.D. Thesis, University of Cape Town, Cape Town, South Africa, 2021.

67. Alvarez-Silva, M.; Wiese, J.; O'Connor, C.T. An investigation into the role of froth phase in controlling chromite in the flotation of UG2 ore using laboratory column flotation cell. Miner. Eng. 2013, 55, 125-131. [CrossRef] 
68. Hay, M.P. A case study of optimizing UG2 flotation performance. Part 2: Modelling improved PGM recovery and Cr2O3 rejection at Northam's UG2 concentrator. Miner. Eng. 2010, 23, 868-876. [CrossRef]

69. Maharaj, L.; Loveday, B.K.; Pocock, J. Gravity separation of a UG-2 ore secondary sample for the reduction of chromite minerals. Miner. Eng. 2012, 30, 99-101. [CrossRef]

70. Achaye, I.; Wiese, J.; McFadzean, B. Effect of mineral particle size on froth stability. Miner. Process. Extr. Metall. 2019. [CrossRef]

71. McFadzean, B.; Marozva, T.; Wiese, J. Flotation frother mixtures: Decoupling the sub-processes of froth stability, froth recovery and entrainment. Miner. Eng. 2016, 85, 72-79. [CrossRef]

72. Nyabeze, W.; McFadzean, B. Adsorption of copper sulphate on PGM-bearing ores and its influence on froth stability and flotation kinetics. Miner. Eng. 2016, 92, 28-36. [CrossRef]

73. Cruz, N.; Forster, J.; Bobicki, E.R. Slurry rheology in mineral processing unit operations: A critical review. Can. J. Chem. Eng. 2019, 97, 2102-2120. [CrossRef]

74. Ndlovu, B.; Becker, M.; Forbes, E.; Deglon, D.; Franzidis, J.-P. The influence of phyllosilicate mineralogy on the rheology of mineral slurries. Miner. Eng. 2011, 24, 1314-1322. [CrossRef]

75. Ndlovu, B.N.; Burdukova, E.; Becker, M.; Deglon, D.; Franzidis, J.P.; Laskowski, J.S. The effects of chrysotile mineralogical properties on the rheology of chrysotile suspensions. Miner. Eng. 2011, 24, 1004-1009. [CrossRef]

76. Burdukova, E.; Becker, M.; Ndlovu, B.; Mokgethi, D.; Deglon, D. Relationship between slurry rheology and its mineralogical content. In Proceedings of the 24th International Mineral Processing Congress, Beijing, China, 24-28 September 2008; Science Press: Beijing, China, 2008; pp. 2169-2178.

77. Becker, M.; Yorath, G.; Ndlovu, B.; Harris, M.; Deglon, D.; Franzidis, J.P. A rheological investigation of the behaviour of two Southern African platinum ores. Miner. Eng. 2013, 49, 92-97. [CrossRef]

78. Shi, F.N.; Napier-Munn, T.J. Effects of slurry rheology on industrial grinding performance. Int. J. Miner. Process. 2002, 65, 125-140. [CrossRef]

79. Govender, I.; Tupper, G.; Mainza, A. Towards a mechanistic model for slurry transport in tumbling mills. Miner. Eng. 2011, 24, 230-235. [CrossRef]

80. Narasimha, M.; Mainza, A.; Holtham, P.; Powell, M.; Brennan, M. A semi-mechanistic model of hydrocyclones-Developed from industrial data and inputs from CFD. Int. J. Miner. Process. 2014, 133, 1-12. [CrossRef]

81. Bakker, C.W.; Meyer, C.J.; Deglon, D.A. The development of a cavern model for mechanical flotation cells. Miner. Eng. 2010, 23, 968-972. [CrossRef]

82. Shabalala, N.Z.P.; Harris, M.; Leal Filho, L.S.; Deglon, D.A. Effect of slurry rheology on gas dispersion in a pilot-scale mechanical flotation cell. Miner. Eng. 2011, 24, 1448-1453. [CrossRef]

83. Ralston, J.; Fornaserio, D. Effect of MgO minerals on pentlandite flotation. In Proceedings of the 23rd International Minerals Processing Congress, Istanbul, Turkey, 3-8 September 2006; Onal, G., Acarkan, N., Celik, M.S., Arslan, F., Atesok, G., Guney, A., Sirkeci, A.A., Yuce, A.E., Perek, K.T., Eds.; Promed Advertising Ltd: Istanbul, Turkey, 2006; pp. 750-755.

84. Farrokhpay, S. The importance of rheology in mineral flotation: A review. Miner. Eng. 2012, 36-38, 272-278. [CrossRef]

85. Alexander, D.J.; Franzidis, J.P.; Manlapig, E.V. Froth recovery measurement in plant scale flotation cells. Miner. Eng. 2003, 16, 1197-1203. [CrossRef]

86. Seaman, D.R.; Franzidis, J.P.; Manlapig, E.V. Bubble load measurement in the pulp zone of industrial flotation machines-A new device for determining the froth recovery of attached particles. Int. J. Miner. Process. 2004, 74, 1-13. [CrossRef]

87. Yianatos, J.B.; Moys, M.H.; Contreras, F.A.V. Froth recovery of industrial flotation cells. Miner. Eng. 2008, 21, 817-825. [CrossRef]

88. Franzidis, J.P.; Harris, M.C. Froth recovery factor-What is it and why is it so difficult to measure? Can. Metall. Q. 2010, 49, 337-344. [CrossRef]

89. Shi, F.N.; Zheng, X.F. The rheology of flotation froths. Int. J. Miner. Process. 2003, 69, 115-128. [CrossRef]

90. Li, C.; Farrokhpay, S.; Runge, K.; Shi, F. Determining the significance of flotation variables on froth rheology using a central composite rotatable design. Powder Technol. 2016, 287, 216-255. [CrossRef]

91. Li, C.; Runge, K.; Shi, F.; Farrokhpay, S. Effect of flotation froth properties on froth rheology. Powder Technol. 2016, 294, 55-65. [CrossRef]

92. Li, C.; Runge, K.; Shi, F.; Farrokhpay, S. Effect of froth rheology on froth and flotation performance. Miner. Eng. 2018, 115, 4-12. [CrossRef]

93. Li, C.; Runge, K.; Shi, F.; Farrokhpay, S. Effect of flotation conditions on froth rheology. Powder Technol. 2018, 340, 537-542. [CrossRef]

94. Nguyen, Q.D.; Boger, D.V. Application of rheology to solving tailings disposal problems. Miner. Eng. 1998, $24,1314-1322$. [CrossRef]

95. Shackleton, N.J.; Malysiak, V.; O'Connor, C.T. Surface characteristics and flotation behaviour of platinum and palladium tellurides. Miner. Eng. 2007, 20, 1232-1245. [CrossRef]

96. Shackleton, N.J.; Malysiak, V.; O'Connor, C.T. Surface characteristics and flotation behaviour of platinum and palladium arsenides. Int. J. Miner. Process. 2007, 85, 25-40. [CrossRef]

97. Molifie, A.; McFadzean, B.; Becker, M.; Geldenhuys, S. Investigating the use of sodium metasilicate to improve the flotation performance of altered PGE ores. In Proceedings of the XXVIII International Mineral Processing Congress, Cape Town, South Africa, 18-22 October 2020. 
98. Ndlovu, B.; Forbes, E.; Farrokhpay, S.; Becker, M.; Bradshaw, D.; Deglon, D. A preliminary rheological classification of phyllosilicate group minerals. Miner. Eng. 2014, 55, 190-200. [CrossRef]

99. Bhosale, P.S.; Berg, J.C. Poly(acrylic acid) as a rheology modifier for dense alumina dispersions in high ionic strength environments. Colloids Surf. A 2010, 362, 71-76. [CrossRef]

100. Pearse, M.J. An overview of the use of chemical reagents in mineral processing. Miner. Eng. 2005, 18, 139-149. [CrossRef]

101. Choi, H.; Lee, W.; Kim, S. Effect of grinding aids on the kinetics of fine grinding energy consumed of calcite powders by a stirred ball mill. Adv. Powder Technol. 2009, 20, 350-354. [CrossRef]

102. Mosa, E.S.; Saleh, A.M.; Taha, T.A.; El-Molla, A.M. Effect of chemical additives on flow characteristics of coal slurries. Physicochem. Probl. Miner. Process. 2008, 42, 107-118.

103. Ross, V.; Singh, A.; Pillay, K. Improved flotation of PGM tailings with a high-shear hydrodynamic cavitation device. Miner. Eng. 2019, 137, 133-139. [CrossRef] 